\title{
Sulfur isotope ratios of some Japanese skarn deposits
}

\author{
Hidehiko Shimazaki $^{1}$ and Masahiro Yamamoto ${ }^{2}$ \\ Geological Institute, Faculty of Science, University of Tokyo, Tokyo $113^{1}$, and \\ Department of Earth Science, Faculty of Science, Okayama University, Okayama $700^{2}$, Japan
}

(Received November 22, 1979)

\begin{abstract}
Sulfur isotope study of some Japanese skarn deposits of ilmenite-series granitoid affinity shows that sulfide minerals have $\delta^{34} \mathrm{~S}$ values ranging from +0.7 to $-12.2 \%$. The remarkable negative $\delta^{34} \mathrm{~S}$ trend in the studied deposits gives support to an idea by SASAKI and ISHIHARA (in press) that there is a distinct parallelism between the sulfur isotopic data of rock sulfur and ore sulfur from magnetite- and ilmeniteseries of granitoids in Japan. $\delta^{34} \mathrm{~S}$ values of 25 sulfide samples from the Tsumo mining area fall in a very narrow range from +0.7 to $-1.7 \%$, irrespective of their various occurrences. $\delta^{34} \mathrm{~S}$ values for sulfide sulfur of the Kawayama mine are negative and moderately large, suggesting contact metasomatic origin of the deposit. $\delta^{34} \mathrm{~S}$ values of paired sulfide minerals are sometimes closer to each other than, or have in some cases reverse relation to, those expected from published experimental results.
\end{abstract}

\section{INTRODUCTION}

Many studies on sulfur isotopes in various sulfide ore deposits have clearly shown that the sulfur isotope study is indispensable for understanding the origin of sulfur and physico-chemical features prevailing in the ore-forming process. In addition, recent reconnaissance study by SASAKI and ISHIHARA (in press) demonstrated a certain correlation between isotope ratios of sulfur from some Japanese hydrothermal ore deposits and from granitic rocks which have presumably genetic relation to the deposits, and suggested that sulfur isotope studies could give fundamental data for discussing the genetic relation between acid magmatism and ore deposition.

Because only little is known about isotope ratios of sulfide sulfur from Japanese hydrothermal vein and skarn deposits (Yамамото, 1974, 1976; KIYOSU, 1977; KIYOSU and NAKAI, 1977; SASAKI and IsHIHARA, in press), the present writers have planned to determine sulfur isotope ratios of hydrothermal deposits as many as possible. The result given in the present paper is a part of those obtained through this project, which is still continued by the writers.
The locality of the deposits discussed in this paper is given in Fig. 1. These deposits were selected first in. the project, because some features in the deposits suggest relatively reducing environments achieved at the time of mineral deposition. Most of sulfides in these deposits were precipitated with pyrrhotites, and their sulfur isotope ratios are thought to be close to isotope ratios of total sulfur dissolved in the hydrothermal solutions responsible for the formation of these deposits. All deposits studied are skarn-type, associated with acid igneous activities of late Cretaceous, except one deposit, Hoei mine, which is related to Miocene Ohkueyama acid igneous complex. The igneous activities related to the deposits studied here, are classified into ilmenite-series granitoids by ISHIHARA (1977), and relatively reducing nature of the hydrothermal solutions responsible for these deposits, is supposed to be genetically related to the nature of granitic magmas (SHIMAZAKI, in press).

\section{OUTLINE OF ORE DEPOSITS}

The Kagata tungsten mine The mine is located about $90 \mathrm{~km}$ north-northeast of Tokyo. 


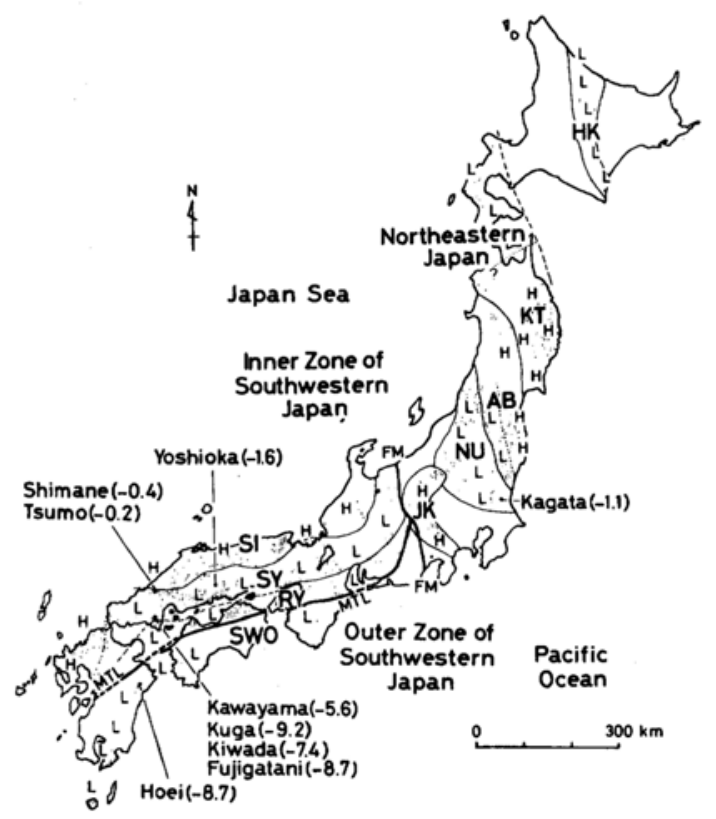

Fig. 1. Locality map of skarn deposits studied. Figures in parentheses are averaged $\delta^{34} S(\%)$ values for chalcopyrite (pyrrhotite for the Hoei mine) from each mine. Dotted area shows the distribution of granitoids, and $H$ and $L$ mean granitic belts of magnetiteand ilmenite-series, respectively (modified from IsHIHARA, 1977). FM Fossa Magna. MTL: Median Tectonic Line. HK: Hidaka, KT: Kitakami, AB: Abukuma, NU: Nikko-Uetsu, JK: Joshin-Kobu, SI: SaninShirakawa, SY: Sanyo-Naegi, RY: Ryoke, and SWO: Outer Zone of Southwestern Japan granitic belts.

The area consists of Late Paleozoic shale, sandstone, chert and thin lenses of limestone, intruded by Late Cretaceous biotite granite. Although the mine was closed about 25 years ago, the specimen including sulfide minerals was collected from an old dump. The main constituent minerals of the deposits are grossular, ferrosalite to hedenbergite, wollastonite, ferrobustamite, actinolite, scheelite, pyrrhotite, pyrite and chalcopyrite (SHIMAZAKI and YAMANAKA, 1973; SHIMAZAKI, 1977).

The Yoshioka copper mine The mine is located about $50 \mathrm{~km}$ west-northwest of Okayama City. Although many vein-type copper deposits extend in Sangun metamorphic rocks of phyllite, slate and chlorite schist, and in unmetamorphosed shale and sandstone of Triassic age, the Sasano copper deposit studied here is a skarn- type formed in the latter. The area is intruded by many stocks of acid porphyritic rocks of Late Cretaceous. The central part of the Sasano skarn deposit consists of clinopyroxene and hastingsite with small amounts of epidote, sphene, apatite, pyrrhotite and chalcopyrite. White skarn consisting of plagioclase, clinopyroxene and minor sphene, is always present along the boundary between clinopyroxenehastingsite skarn and shale, surrounding the former. A pipe-like shape of the deposit indicates that these skarns are formed mainly from shale through the reaction with calcium-bearing hydrothermal solution.

The Tsumo mining area The area is located about $20 \mathrm{~km}$ east-southeast of Masuda City, Shimane Prefecture. The area is occupied by slate, sandstone, chert, limestone and basic rocks of Sangun metamorphic belt (ОнтA et al., 1970). The sedimentary rocks are intruded by various igneous rocks of Cretaceous age, and many skarn deposits of copper, zinc, lead and tungsten are formed with genetical relation to the igneous activity. The specimens studied were collected from the Maruyama, Horai, Tsumo and Asahi deposits of the Tsumo mine, and also from the Shimane mine. These skarn deposits are arranged in relatively narrow area of about $3 \mathrm{~km}$ long along the N-S direction, although the natute of the skarn and ore is considerably variable (SHIMAZAKI, 1968a, b).

The Kuga mining area The area is situated about $50 \mathrm{~km}$ west-southwest of Hiroshima City. In the area of about $15 \mathrm{~km}$ along the N-S direction and about $10 \mathrm{~km}$ along the E-W, there are three tungsten skarn mines named Kuga, Fujigatani and Kiwada, and one copper-zinc skarn mine named Kawayama. The tungsten skarn deposits with minor copper are found in Upper Paleozoic to Lower Mesozoic formations of slate, sandstone, chert and limestone. These rocks are intruded by Late Cretaceous granitic rocks at the southern part of the area. The skarn and ore from these three mines have similar characteristics to each other, and also to those from 
the Kagata mine mentioned above. General feature of these deposits is given elsewhere (e.g. IмAI and Iто, 1959; Iто, 1962), and ferricpoor nature of the skarns is emphasized by SHIMAZAKI (1977).

The geology of the Kawayama mine is rather complicated. The massive copper-zinc deposit is formed along a limestone horizon in black phyllite of Sangun metamorphic belt. Sangun metamorphic rocks including the deposit thrust over the unmetamorphosed formations of Upper Paleozoic to Lower Mesozoic. Rhyolite dikes and lava flows of Late Cretaceous are observed near the deposit, and are thought to be the effusive equivalent of the granitic rocks mentioned above. The ore of the mine consists mainly of pyrrhotite, chalcopyrite and sphalerite, and is occasionally associated with skarn minerals such as andradite, hedenbergite and lievrite, especially at the lower parts of the deposit (NAKAMURA and AIKAWA, 1974). Because of massive and apparently concordant nature of the deposit to host rocks, the genesis of the Kawayama deposit has been debated for a long time. For example, the deposit was classified as one of syngenetic massive sulfide deposits (so-called Kieslagertype deposits) in Sangun metamorphic belt (Japan Mining Industry Association, 1965). The present isotopic study was carried out in the hope of shedding light on the genesis of the deposit.

The Hoei tin-zinc mine The mine is located about $45 \mathrm{~km}$ south-southwest of Oita City. The area consists of Paleozoic formations of slate and limestone, intruded by acid igneous rocks of Miocene. The area is characterized by the presence of many ore deposits of tin, zinc, lead, copper, bismuth and arsenic, and they are thought to have genetical relation to the Ohkueyama granitic intrusion and its coeval acid volcanism (MryaHISA, 1961). The samples used in the present study were collected from No. 1 and No. 2 Ore Bodies of the mine. According to MrYAHISA and NodA (1964), the mineralization starts with the formation of skarn minerals such as garnet, wollastonite and vesuvianite, followed by sphalerite and pyrrhotite. Later mineraliza- tion is characterized by the precipitation of coarse-grained pyrite, marcasite, arsenopyrite, sphalerite, quartz and fluorite with small amounts of tin minerals such as cassiterite and stannite.

\section{EXPERIMENTAL}

Sulfide minerals were separated from hand specimens by hand picking, and isodynamic separator and/or a hand magnet. Purity of sulfide minerals is more than $95 \mathrm{vol}$. percent in most cases. Some sphalerites from the Tsumo and Kawayama mines have blebs of pyrrhotite and/or chalcopyrite, and the amount of impurity reaches 10 vol. percent in some cases. All sulfide minerals were finally converted to $\mathrm{Ag}_{2} \mathrm{~S}$ by the procedure described by THODE et al. (1961). $\mathrm{Ag}_{2} \mathrm{~S}$ obtained was combusted to $\mathrm{SO}_{2}$ at $1,200^{\circ} \mathrm{C}$ in a stream of tank air for the mass spectrometry. The mass spectrometer used for the isotope analysis has been described by SAKAI (1966). The results of the isotope analysis are given in $\delta^{34} \mathrm{~S}$ value as defined by:

$$
\begin{gathered}
\delta^{34} \mathrm{~S}(\% 0)=\left[\left({ }^{34} \mathrm{~S} /{ }^{32} \mathrm{~S}\right)_{\text {sample }} /\left({ }^{34} \mathrm{~S} /{ }^{32} \mathrm{~S}\right)_{\text {standard }}-1\right] \\
\times 1,000
\end{gathered}
$$

The standard is troilite sulfur from the Canyon Diablo meteorite. The uncertainty in $\delta^{34} \mathrm{~S}$ values is less than $\pm 0.2 \%$ in most cases.

\section{RESUlTS AND DisCUSSION}

Sulfur isotope data obtained are summarized in Table 1. Distribution of $\delta^{34} \mathrm{~S}$ values of sulfide minerals from the Tsumo mining area is graphically shown in Fig. 2.

${ }^{34} \mathrm{~S}$ depletion in some deposits As shown in Table 1, all sulfide minerals studied have negative $\delta^{34} \mathrm{~S}$ values with a few exceptions from the Tsumo mine. Among them, samples from the Kuga mining area and the Hoei mine show large negative values. As stated before, these deposits were selected in the present study because of certain features suggesting relatively reducing environments for the ore deposition. For 
Table 1. Sulfur isotopic composition of sulfide minerals from some Japanese skarn deposits

\begin{tabular}{|c|c|c|c|c|c|c|}
\hline No. & Sample No. & \multicolumn{2}{|l|}{ Locality } & Rock & Mineral & ${ }^{34} \mathrm{~S}(\% 0)$ \\
\hline \multicolumn{7}{|c|}{ Kagata mine, Ibaraki Prefecture, $-1.3--1.1(\% 0)(2)$} \\
\hline $\begin{array}{l}1 \\
2\end{array}$ & HS72072313 & \multicolumn{2}{|l|}{ Dump } & Cpx sk & $\begin{array}{l}\text { cp } \\
\text { po }\end{array}$ & $\begin{array}{l}-1.1 \\
-1.3\end{array}$ \\
\hline \multicolumn{7}{|c|}{ Yoshioka mine, Okayama Prefecture, $-1.9--1.1(\%)(6)$} \\
\hline $\begin{array}{l}3 \\
4\end{array}$ & HS71112705 & \multicolumn{2}{|c|}{ Sasano D, No. 1 OB, No. $1 \mathrm{~L}$} & Massive $\mathrm{Cu}$ ore & $\begin{array}{l}\text { cp } \\
\text { po }\end{array}$ & $\begin{array}{l}-1.9 \\
-1.6\end{array}$ \\
\hline 5 & HS71112706 & \multirow{2}{*}{\multicolumn{2}{|c|}{ ditto }} & ditto & cp & -1.3 \\
\hline 6 & & & & & po & -1.1 \\
\hline 7 & HS71112710 & \multirow{2}{*}{\multicolumn{2}{|c|}{ ditto }} & dit to & cp & -1.6 \\
\hline 8 & & & & & po & -1.3 \\
\hline \multicolumn{7}{|c|}{ Tsumo mine, Shimane Prefecture, $-1.7-+0.7(\% 0)(24)$} \\
\hline 9 & TM-SP 2 & Maruyama D, & $-10 \mathrm{~mL}$ & Massive $\mathrm{Zn}$ ore & sp & 0.0 \\
\hline 10 & HS62081201 & ditto & $-25 \mathrm{~mL}$ & ditto & $\mathrm{sp}$ & -0.1 \\
\hline 11 & HS62081802 & ditto & & Gar-woll sk & gn & -1.2 \\
\hline 12 & & & & & $\mathrm{sp}$ & -0.2 \\
\hline 13 & HS76102503 & ditto & $-50 \mathrm{~mL}$ & Gar sk & $\mathrm{cp}$ & -0.1 \\
\hline 14 & & & & & sp & +0.1 \\
\hline 15 & HS76102501 & ditto & & Gar-woll sk & sp & -0.2 \\
\hline 16 & HS76102514 & ditto & $-75 \mathrm{~mL}$ & Cpx sk & gn & -1.5 \\
\hline 17 & & & & & $\mathrm{sp}$ & 0.0 \\
\hline 18 & HS75100320 & ditto & $-125 \mathrm{~mL}$ & Massive $\mathrm{Pb}-\mathrm{Cu}$ ore & gn & -1.6 \\
\hline 19 & & & & & po & -0.7 \\
\hline 20 & HS76080605 & ditto & $-1500 \mathrm{~mL}$ & Massive $\mathrm{Cu}$ ore & $\mathrm{cp}$ & -0.3 \\
\hline 21 & HS76031105 & ditto & $-225 \mathrm{~mL}$ & Massive $\mathrm{Cu}-\mathrm{Zn}$ ore & $\mathrm{cp}$ & +0.1 \\
\hline 22 & & & & & $\mathrm{sp}$ & -0.1 \\
\hline 23 & HS76102706 & ditto & & Cpx sk & $\mathrm{cp}$ & -0.4 \\
\hline 24 & HS76031108 & ditto & & Cpx-Qtz-Sch vein & cp & -0.3 \\
\hline 25 & HS76102615 & ditto & $-250 \mathrm{~mL}$ & Cpx-gar sk & $\mathrm{cp}$ & +0.1 \\
\hline 26 & HS76102612 & ditto & $-275 \mathrm{~mL}$ & Cpx sk & $\mathrm{cp}$ & -0.4 \\
\hline 27 & & & & & po & +0.2 \\
\hline 28 & HS76080601 & Horai D, & $0 \mathrm{~mL}$ & Sch-bearing po ore & po & +0.7 \\
\hline 29 & HS76080602 & ditto & $-25 \mathrm{~mL}$ & ditto & po & +0.3 \\
\hline 30 & HS76080603 & ditto & $-50 \mathrm{~mL}$ & ditto & po & +0.3 \\
\hline 31 & HS62082907 & Tsumo D, & $-25 \mathrm{~mL}$ & Chon-phl-trm sk & po & -0.1 \\
\hline 32 & HS71102607 & Asahi D & & Bn-bearing $\mathrm{Cu}$ ore & $\mathrm{cp}$ & -1.7 \\
\hline \multicolumn{7}{|c|}{ Shimane mine, Shimane Prefecture, $-0.4(\% 0)(1)$} \\
\hline 33 & SHIMANE 1 & Dump & & Massive $\mathrm{Cu}$ ore & $\mathrm{cp}$ & -0.4 \\
\hline \multicolumn{7}{|c|}{ Kawayama mine, Yamaguchi Prefecture, $-6.3--4.6(\% 0)(16)$} \\
\hline 34 & HS63072306 & $80 \mathrm{~mL}$ & & Massive $\mathrm{Cu}$ ore & po & -6.1 \\
\hline 35 & TT63111202 & $80-110 \mathrm{~mL}$ & & ditto & $\mathrm{cp}$ & -5.6 \\
\hline 36 & & & & & po & -6.2 \\
\hline 37 & HS63072202 & $110 \mathrm{~mL}$ & & Act sk & po & -6.1 \\
\hline 38 & TT63111201 & ditto & & Massive $\mathrm{Cu}$ ore & $\mathrm{cp}$ & -5.8 \\
\hline 39 & & & & & po & -6.3 \\
\hline 40 & HS63072410 & $140 \mathrm{~mL}$ & & Cpx sk & sp & -5.5 \\
\hline 41 & HS63072302 & $210 \mathrm{~mL}$ & & Liev-gar sk & po & -5.6 \\
\hline 42 & & & & & sp & -4.9 \\
\hline 43 & HS63072403 & ditto & & Massive $\mathrm{Cu}$ ore & $\mathrm{cp}$ & -5.5 \\
\hline 44 & & & & & po & -6.1 \\
\hline 45 & HS63072408 & ditto & & ditto & po & -6.0 \\
\hline 46 & HS63072401 & $210-240 \mathrm{~mL}$ & & Massive $\mathrm{Zn}$ ore & sp & -5.6 \\
\hline 47 & HS63072402 & ditto & & ditto & po & -5.9 \\
\hline 48 & & & & & sp & -5.5 \\
\hline 49 & HS63072303 & $240 \mathrm{~mL}$ & & Cpx sk & sp & -4.6 \\
\hline \multicolumn{7}{|c|}{ Kuga mine, Yamaguchi Prefecture, $-9.2--8.3(\% 0)(4)$} \\
\hline 50 & HS72081817 & Taiho D, Main & & Gar sk & $\mathrm{cp}$ & -9.2 \\
\hline 51 & & & & & po & -9.2 \\
\hline 52 & HS72081825 & Ideno-oku D, & No. $4 \mathrm{OB}, 80 \mathrm{ml}$ & LCpx sk & gn & -9.2 \\
\hline 53 & & & & & po & -8.3 \\
\hline
\end{tabular}




\begin{tabular}{|c|c|c|c|c|c|}
\hline No. & Sample No. & Locality & Rock & Mineral & ${ }^{34} \mathrm{~S}(\%)$ \\
\hline \multicolumn{6}{|c|}{ Fujigatani mine, Yamaguchi Prefecture, $-12.2--6.9(\% 0)(10)$} \\
\hline $\begin{array}{l}54 \\
55\end{array}$ & HS72081623 & Akemidani No. $1 \mathrm{OB},-20 \mathrm{~mL}$ & Qtz-chl rock & $\begin{array}{l}\text { gn } \\
\text { po }\end{array}$ & $\begin{array}{r}-10.0 \\
-8.6\end{array}$ \\
\hline 56 & HS72081706 & No. 2 OB, $-80 \mathrm{~mL}$ & Massive $\mathrm{Cu}$ ore & $\mathrm{cp}$ & -8.4 \\
\hline 57 & & & & po & -9.6 \\
\hline 58 & HS72081605 & $-100 \mathrm{~mL}$ & ditto & $\mathrm{cp}$ & -11.8 \\
\hline 59 & & & & po & -12.2 \\
\hline 60 & HS76112305 & No. $5 \mathrm{OB},-40 \mathrm{~mL}$ & Cpx sk & po & -7.9 \\
\hline 61 & HS76112306 & ditto & Qtz vein & cp & -7.6 \\
\hline 62 & HS76112303 & $-80 \mathrm{~mL}$ & ditto & cp & -6.9 \\
\hline 63 & HS76112304 & ditto & Hbd sk & po & -11.3 \\
\hline \multicolumn{6}{|c|}{ Kiwada mine, Yamaguchi Prefecture, $-8.5--7.1(\% 0)(8)$} \\
\hline 64 & HS72081909 & Ohgiri D, No. 5 OB & Qtz-chl rock & py & -7.5 \\
\hline 65 & HS76112211 & ditto No. 8 OB & Cpx-qtz sk & po & -8.5 \\
\hline 66 & HS72081921 & Shin-ei, D dump & Qtz-sch rock & py & -8.4 \\
\hline 67 & HS76112201 & Choei D & Massive $\mathrm{Cu}$ ore & cp & -7.1 \\
\hline 68 & HS76112207 & ditto & ditto & $\mathrm{cp}$ & -7.6 \\
\hline 69 & & & & po & -7.7 \\
\hline 70 & HS76112208 & ditto & gar sk & po & -7.6 \\
\hline 71 & & & & py & -7.5 \\
\hline \multicolumn{6}{|c|}{ Hoei mine, Oita Prefecture, $-9.0--8.7(\% 0)(8)$} \\
\hline 72 & HS73031304 & No. $1 \mathrm{OB}, 0 \mathrm{~mL}$ & Massive $\mathrm{Sn}-\mathrm{Zn}$ ore & $\mathrm{sp}$ & -9.0 \\
\hline 73 & & & & py & -8.9 \\
\hline 74 & HS73031315 & $-30 \mathrm{~mL}$ & ditto & sp & -8.8 \\
\hline 75 & & & & py & -8.9 \\
\hline 76 & HS73031424 & ditto & ditto & py-1 & -8.9 \\
\hline 77 & & & & py-2 & -8.8 \\
\hline 78 & & & & py-3 & -9.0 \\
\hline 79 & HS73031405 & No. $2 \mathrm{OB},-75 \mathrm{~mL}$ & Po ore & po & -8.7 \\
\hline
\end{tabular}

Abbreviations: act: actinolite, bn: bornite, chl: chlorite, chon: chondrodite, cp: chalcopyrite, cpx: clinopyroxene, D: deposit, gar: garnet, gn: galena, hbd: hornblende, L: level, liev: lievrite, OB: ore body, phl: phlogopite, po: pyrrhotite, qtz: quartz, sch: scheelite, sk: skarn, sp: sphalerite, trm: tremolite, woll: wollastonite.

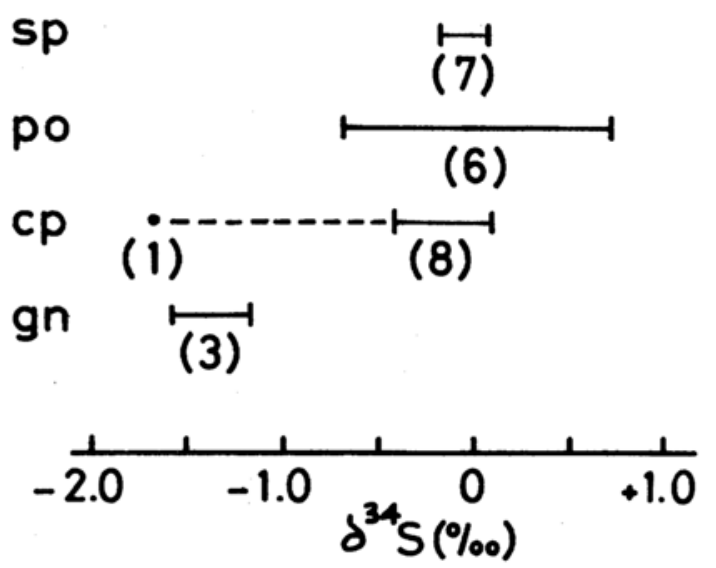

Fig. 2. Distribution of sulfur isotopes of sulfide minerals from the Tsumo mining area.

Abbreviations are the same as given in Table 1. Figures in parentheses are numbers of analysis. example, pyrrhotite is predominant in all deposits, and no hematite is reported to the present authors' knowledge. On the basis of these facts, it could be stated that reduced sulfur species such as $\mathrm{H}_{2} \mathrm{~S}, \mathrm{HS}^{-}$and $\mathrm{S}^{--}$, predominated in the ore-forming solutions. It is well known that the isotopic fractionation is not large between reduced sulfur species in the aqueous solution and sulfide sulfur in equilibrium with the solution at temperatures for the hydrothermal ore deposition (SAKAI, 1968). The sulfur isotopic compositions given in Table 1 are not much different from those for total sulfur in the ore-forming solutions. Although the source of such light sulfur, found especially in the Kuga mining area and Hoei mine, is not clear at the present time, it is most likely biogenic sulfur contained in sedimentary rocks as suggested by SASAKI and IsHIHARA (1979). 
As shown in Fig. 1, all deposits studied here are located in the regions where activities of ilmenite-series granitoids are recognized. The averaged $\delta^{34} \mathrm{~S}$ values for chalcopyrites from each mine are included in Fig. 1 for comparison. For the Hoei mine, the averaged value for pyrrhotite is plotted because no data on chalcopyrite is available. Although some $\delta^{34} \mathrm{~S}$ values given in Table 1 might not be representative of the deposits due to only limited sampling and measurements, the negative $\delta^{34} \mathrm{~S}$ trend is apparent for the deposits in the region of ilmenite-series granitoids. These data give support to the idea given by SASAKI and IsHIHARA (in press), namely that ore sulfurs of granitic affinity have parallel isotopic trends with the rock sulfur.

\section{The Tsumo mining area As stated previously,} there are many skarn deposits in the area. Common are copper ores and zinc and lead ores found in garnet-clinopyroxene skarns. Besides them, massive pyrrhotite-scheelite ores are exploited at the Horai deposit, and clinopyroxenequartz-scheelite veins occur at the deeper parts of the Maruyama deposit cutting the preexisting garnet-clinopyroxene skarns. It is worthy of mentioning that, as clearly demonstrated in Fig. 2, 25 sulfide samples of various occurrences in this area, show a very narrow range of $\delta^{34} \mathrm{~S}$ values, namely from -1.7 to $+0.7 \%$. In the Maruyama deposit, samples were taken from several levels of -10 to $-275 \mathrm{~m}$, and no systematic change in the $\delta^{34} \mathrm{~S}$ values of sulfide sulfur is recognized. These facts could be interpreted as 1) sulfur in various stages of mineralization found in this area was brought from one large homogeneous 'source, 2) physico-chemical environments were rather constant during all stages of mineralization, and 3) the metal-sulfur ratio in the ore-forming solution was considerably small, and the precipitation of sulfide minerals did not give any effects on the isotopic composition of total sulfur in the solution.

The Kawayama mine The $\delta^{34} \mathrm{~S}$ values of sulfide sulfur of the Kawayama deposit are negative and moderately large. No systematic change is observed in the samples with or without skarns from 80 to $240 \mathrm{~mL}$. The $\delta^{34} \mathrm{~S}$ values of this mine are close to, but slightly heavier than, those of the scheelite skarn deposits found in this area. Although the cause of the difference in the $\delta^{34} \mathrm{~S}$ value of each mine, is not clear at the present time, these data strongly suggest that sulfur in the Kawayama and scheelite skarn deposits is derived from similar sources. As stated previously, the Kawayama deposit is believed by many people to be an example of syngenetic massive sulfide deposits in Sangun metamorphic belt. Only little is known about isotopic ratios of sulfide sulfur from such deposits except for the work by Yamamoto et al. (1968) on the Yanahara mine, Okayama Prefecture, which could be cited as a representative deposit in Sangun metamorphic belt. According to them, averaged $\delta^{34} \mathrm{~S}$ value of sulfide sulfur (mainly of pyrite and pyrrhotite) from the Yanahara mine is $+2.8 \%$, and is much different from the value, $-5.7 \%$, of the Kawayama mine.

Temperature estimation From some samples, two sulfide minerals coexisting grain by grain were separated for the isotopic analysis. These pairs are shown in Table 1 with the same sample numbers. Temperature estimation for these coexisting sulfide minerals using experimental temperature scales given by KaJIWARA and KROUSE (1971), gives considerably high temperatures such as 400 to $700^{\circ} \mathrm{C}$. In addition, some paris have isotopic concentrations reverse to the trend expected from the experiments. For example, ${ }^{34} \mathrm{~S}$ is always concentrated in chalcopyrite compared with coexisting pyrrhotite in studied pairs from the Kawayama mine (Nos. 35-36, 38-39 and 43-44 in Table 1). High temperatures given by sulfur isotope thermometry are partly caused by poor separation. Some pairs, however, give still higher temperatures after the correction due to impurities. Poor purification of paired samples is mostly derived from the contamination of the paired sulfide mineral. Then the reverse concentration of sulfur isotopes between sulfide minerals is 
hard to explain by the poor separation.

One possible explanation is that the temperature scales obtained by experimental works are not completely correct. Isotopic fractionation, for example, between sphalerite and pyrrhotite was not ascertained in the work by KAJIWARA and Krouse (1971). In the study on sulfur isotope ratios of ores from the Taishu mine, however, KIYosu (1977) recognized that pyrrhotite is several tenth permil depleted in ${ }^{34} \mathrm{~S}$ compared with the associated sphalerite. This relation is also confirmed in two pairs from the Kawayama mine (Nos. 41-42 and 47-48 in Table 1). Sphalerite associated with pyrrhotite contains considerable amounts of FeS molecule, and may show different behavior from pure sphalerite as to sulfur isotope fractionation. Experimental works on the $\mathrm{Cu}-\mathrm{Fe}-\mathrm{S}$ system (e.g. YUND and KULlERUD, 1966) show that chalcopyrite and pyrrhotite make so-called intermediate solid solution to a considerable extent under relatively high temperatures. Most of chalcopyrite and pyrrhotite from skarn deposits, therefore, have probably experienced certain phase transitions after the precipitation from the aqueous solution. The effect of such subsolidus phase changes on sulfur isotope distribution among sulfide minerals, may be one of the reasons for the relations obtained in the present study. It is also possible that sulfur isotopic equilibrium has not completely been attained among sulfide minerals in these ore deposits, although they apparently coexist with each other. Further experimental works and theoretical consideration would be necessary to understand the distribution of sulfur isotopes among sulfide minerals.

Acknowledgments-The authors are deeply indebted to Professor H. SAKAI of the Thermal Spring Institute, Okayama University, for his helpful advice and support in the mass spectrometry. This work was partly supported by a Grant in Aid for Scientific Research No. 154287 from the Ministry of Education of Japan to one of the authors (HS).

\section{REFERENCES}

IMAI, H. and ITO, K. (1959) Geologic structure and tungsten-copper mineralization of the Kuga mine, Yamaguchi Prefecture. Mining Geol. 9, 95-100 (in Japanese).

ISHIHARA, S. (1977) The magnetite-series and ilmenite-series granitic rocks. Mining Geol. 27, 293305.

ITO, K. (1962) Zoned skarn of the Fujigatani mine, Yamaguchi Prefecture. Japan. J. Geol. Geogr. 33, 169-190.

Japan Mining Industry Association (1965) Ore deposits in Japan (I). Japan Mining Industry Assoc., Tokyo 581 p. (in Japanese).

KaJIWARA, Y. and Krouse, H. R. (1971) Sulfur isotope partitioning in metallic sulfide systems. Can. J. Earth Sci. 8, 1397-1408.

KIYOSU, Y. (1977) Sulfur isotope ratios of ores and chemical environment of ore deposition in the Taishu $\mathrm{Pb}-\mathrm{Zn}$ sulfide deposits, Japan. Geochem. J. 11, 91-99.

KIYOSU, Y. and NAKAI, N. (1977) Estimation of formation temperature for the Taishu, Toyoha and Kamioka $\mathrm{Pb}-\mathrm{Zn}$ deposits on the basis of sulfur isotope temperature scale. J. Japan. Assoc. Mineral. Petr. Econ. Geol. 72, 103-108 (in Japanese).

MIYAHISA, M. (1961) Geological studies on the ore deposits of Obira-type in Kyushu. (I) General geology and metallogenetic provinces. Japan. J. Geol. Georg. $32,39-54$.

MiYAHISA, M. and NoDA, M. (1964) Herzenbergite and associated minerals from the Hoei tin mine, Kyushu, Japan. Mineral. J. 6, 349-360 (in Japanese).

NAKAMURA, T. and AIKAWA, N. (1974) Pyrrhotite and its mineral association at the Kawayama mine, Japan. Mineral. J. Spec. Issue 2, 107-115 (in Japanese).

OHTA, S., AKatsuKa, M. and Honda, T. (1970) Geology, ore deposits and prospecting of the Tsumo mine. Mining Geol. 20, 267-275 (in Japanese).

SAKAI, H. (1966) Mass spectrometer systems for the isotope ratio of volatile elements. Mass Spectr. 14, $72-77$.

SAKAI, H. (1968) Isotopic properties of sulfur compounds in hydrothermal processes. Geochem. J. 2, 29-49.

SASAKI, A. and IsHIHARA, S. (1979) Sulfur isotopic composition of magnetite-series and ilmenite-series granitoids in Japan. Contr. Mineral. Petr. 68, 107115.

SASAKI, A. and IsHIHARA, S. (in press) Sulfur isotope characteristics of granitoids and related mineral deposits in Japan. Proc. 5th IAGOD Symp.

SHIMAZAKI, H. (1968a) Geology and ore deposits 
of the Tsumo mine, Shimane Prefecture. Japan. J. Geol. Geogr. 39, 55-71.

SHIMAZAKI, H. (1968b) Genesis of pyrometasomatic ore deposits of the Tsumo mine, Shimane Prefecture. Japan. J. Geol. Geogr. 39, 73-87.

SHIMAZAKI, H. (1977) Grossular-spessartine-almandine garnets from some Japanese scheelite skarns. Can. Mineral. 15, 74-80.

SHIMAZAKI, H. (in press) Characteristics of skarn deposits and related acid magmatism in Japan. Econ. Geol.

ShImAZAKI, H. and YamanaKa, T. (1973) Ironwollastonite from skarns and its stability relation in the $\mathrm{CaSiO}_{3}-\mathrm{CaFeSi}_{2} \mathrm{O}_{6}$ join. Geochem. J. 7, 67-79.

Thode, H. G., MONSTER, J. and DUNFORD, H. B.
(1961) Sulfur isotope geochemistry. Geochim. Cosmochim. Acta 25, 565-578.

Yамамото, M. (1974) Distribution of sulfur isotopes in the Ryusei vein of the Akenobe mine, Hyogo Prefecture, Japan. Geochem. J. 8, 75-86.

Yамамото, M. (1976) Relationship between Se/S and sulfur isotope ratios of hydrothermal sulfide minerals. Mineral. Deposita 11, 197-209.

YAMAмото, M., OGUSHI, N. and SAKAI, H. (1968) Distribution of sulfur isotopes, selenium and cobalt in the Yanahara ore deposits, Okayama-ken, Japan. Geochem. J. 2, 137-156.

Yund, R. A. and Kullerud, G. (1966) Thermal stability of assemblages in the Cu-Fe-S system. $J$. Petr. 7, 454-488. 